\title{
Battle lines drawn for make-or-break vote on the future of the SSC
}

Washington. The Superconducting Super Collider will endure its darkest hour today Thursday (24 June) when the US House of Representatives votes on the Texas project's $\$ 620$ million budget allocation for the next financial year.

Formal presidential support for the collider, which finally arrived last week in a letter from President Bill Clinton to William Natcher (Democrat, Kentucky), chairman of the House appropriations committee, was greeted with relief by the 2,000 people already working at the SSC Laboratory near Dallas, but is unlikely to be decisive.

A defeat for SSC in the House of Representatives for the second year running could kill the project. But that outcome is not certain. Last year, support in the Senate and the connivance of a supportive House leadership unlocked the budget allocation.

On the other hand, if SSC survives this year, it is likely that the project will be completed. A total of $\$ 1.5$ billion has so far been spent, and its managers say that work is already 20 per cent complete.

This year support in the Senate, although likely, is by no means assured, and House leaders will have to consider the size of any majority against SSC before deciding how to proceed. George Brown (Democrat, California), the chairman of the House Science, Space and Technology committee, says: "The leadership in the House will decide after the vote how serious it would be if the Senate were to prevail again".

Meanwhile in Texas, four tunnel-boring machines are excavating one mile a week of the 54-mile tunnel that will house the urderground collider, and work has just started on the two huge caverns for the detector equipment. Of the four booster stages that will accelerate particles into the main ring, the building has been completed for the initial linear accelerator and excavations have begun for the first two ring boosters.

A spokesman for the project, Russ Wylie, says the Clinton letter "gave everyone a real uplift", but adds that, in contrast with last year, when the House vote against the SSC had been a nasty surprise, this summer has been a time of "very deep concern" among researchers at Dallas. But Wylie says, "we think it's a winnable vote".

Top physicists have vigorously defended $\mathrm{SSC}$ in the face of increasingly virulent criticism from US politicians and commentators. "The SSC suffers from people not having been down here", says Stan Wojcicki of Stanford University, California, and chairman of the Department of Energy's High Energy Physics Advisory Panel (HEPAP), who is spending a summer sabbatical at the SSC laboratory. "They view it as a paper project. But eight miles of tunnel have already been dug, and the laboratory is really active, holding three or four scientific meetings every week."

Wojcicki says that physicists who have attacked the project (who include his Stan-

\section{IMAGE UNAVAILABLE FOR COPYRIGHT REASONS}

\section{Construction continues apace under the Texan earth as} Congress determines the SSC's fate.

ford colleague Ted Geballe), "are being short-sighted". He says that, if anything, other branches of physics are likely to lose money if SSC goes down.

But in the Congress last week, opponents of the project were moving in for the kill. The estimated total project costs, they say, have grown from $\$ 4.4$ billion in 1987 to $\$ 9$ billion last year, and Clinton's plan (in this year's budget) to "stretch out" the project by up to three years will raise costs by a further \$2 billion.

International collaboration has so far been restricted to contributions from Russia, India and China, which Wylie says are worth "a couple of hundred million dollars" in total. Japan is unwilling to get involved, at least until Congress gives its support this year. European support is similarly unsure; a decision on the competing Large Hadron Collider planned for CERN, at Geneva, is not due until the end of the year.

One House opponent says there will be no substantial foreign contribution and that "SSC supporters know it". Dale Bumpers (Democrat, Arkansas) will lead the attack on the project in the Senate, where the absence of strong support from former Texan senator Lloyd Bentsen (now Secretary of the Treasury) will diminish the project's chances. Last year, the Senate voted $66-33$ for the project, while the House voted $232-181$ to kill it.

The outlook for the project is further clouded by allegations of mismanagement of funds by Universities Research Association Inc, a consortium formed expressly to manage SSC. The House Energy and Commerce committee of John Dingell (Democrat, Michigan) will hold hearings on the matter next week. Friends of the collider say that the charges of mismanagement of funds concern only $\$ 500,000$ out of $\$ 1.5$ billion spent so far on the SSC, are in any case unproven and have been trumped up by SSC's enemies.

In his letter of support, Clinton said that "abandoning the SSC at this point would signal that the United States is compromising its position of leadership in basic science - a position unquestioned for generations."

But the political position of the president is likely to bear heavily on many Congressmen as they vote today. Some Democrats who opposed the project last year will rally to the new president, while Republicans may drift in the opposite direction.

But other Democrats, especially those in the 30 -strong black caucus, may use the issue to vent their disapproval of recent moves by Clinton to appease conservatives with harsh public expenditure cuts that will hit the urban poor. If this improbable alliance of indignant liberals and fiscally stringent conservatives fails to kill the space station in a key vote expected on Wednesday this week, it will be doubly determined to bury the Superconducting Super Collider today.

Colin Macilwain

- Hubert Curien, the former French minister of research, is expected to be elected this week ( 25 June) as the new president of the governing council of CERN, Europe's main laboratory for particle physics. Curien, a geophysicist, was president of the European Space Agency in the early 1980s, and would take up his new position on I January next year. One of the main tasks facing the new president is to negotiate political support for CERN's proposed Large Hadron Collider, the direct competitor to the SSC. 